Vol. 14, $n^{\circ} 1 \mid 2010$

Varia

\title{
McMahon (Richard), Crime, Law and Popular Culture in Europe (1500)
}

Cullompton, Willan Publishing, 2008, 288 pp. , ISBN 9781843921196.

\section{Pieter Spierenburg}

\section{(2) OpenEdition}

\section{Journals}

Electronic version

URL: https://journals.openedition.org/chs/1154

DOI: $10.4000 /$ chs. 1154

ISSN: 1663-4837

\section{Publisher}

Librairie Droz

\section{Printed version}

Date of publication: 1 May 2010

Number of pages: 103-104

ISBN: 978-2-600-01425-0

ISSN: 1422-0857

\section{Electronic reference}

Pieter Spierenburg, "McMahon (Richard), Crime, Law and Popular Culture in Europe (1500)", Crime,

Histoire \& Sociétés / Crime, History \& Societies [Online], Vol. 14, n | 2010, Online since 07 June 2010 connection on 23 March 2022. URL: http://journals.openedition.org/chs/1154 ; DOI: https://doi.org/ $10.4000 /$ chs. 1154 


\section{Comptes rendus Reviews}

\section{McMahon (Richard), Crime, Law and Popular Culture in Europe (1500), Cullompton, Willan Publishing, 2008, 288 pp., ISBN 9781843921196.}

This volume results from a conference organized by the editor in Galway, Ireland. In turning a set of conference papers into a book, each editor faces the difficult task of finding a more or less new theme that provides a measure of unity to the collection. The interaction between crime and popular culture, suggested by the title, is not really a novel theme. In his introduction McMahon specifies it as the relationships between ordinary people and official legal systems. Moreover, he attempts to revive the almost forgotten notion of a «judicial revolution,» proposed three decades ago by Bruce Lenman and Geoffrey Parker. They gave this name to processes of change in Europe that involved a transition from a flexible and relatively non-punitive community law to a more rigid state law that operated from above. Nevertheless, ordinary people increasingly accepted and participated in this state law. Stretching over the four centuries covered by the volume, the judicial revolution is surely one of the longest revolutions in history. Not every contributor explicitly engages with Lenman's and Parker's thesis, but together, according to McMahon, they show that ordinary people were already eager participants in the criminal justice system at the beginning of the early modern period. Presumably, this would make the alleged judicial revolution much speedier.

The order of the nine contributions following upon the introduction is geographic rather than chronological, moving from the Continent to the various islands West of it. First comes France examined by Julius Ruff, who bases his essay on a case study of a conflict between two propertied neighbors in 1785. The Revolution (the French one), Ruff argues, subsequently institutionalized infra-judicial conflict resolution.

Joachim Eibach reviews the evidence about violent crime in a number of German-speaking cities. He concludes, among other things, that the upper classes gradually withdrew from resorting to violence. In cases of petty crime and conflicts people willingly used the courts as prosecutors, but when it came to combating serious crime, courts largely acted upon their own initiative.

Rudy Chaulet presents some results of his work on Castilian pardon letters. Like those for France and the Low Countries, they demonstrate the intimate links between violence and honor and the authorities' tolerance for the culture of selfdefense. To my knowledge, this is the first publication by Chaulet on the subject in English. 
Maria Kaspersson deals with early modern Sweden, arguing that participation in the criminal justice system and cooperation with the law steadily increased. She further discusses such Scandinavian peculiarities as suicidal murders and the courts' increasing concern that no false confessions were made.

James Sharpe extends the historiography of conflict resolution to an area that this reviewer had read nothing about before: the Isle of Man. Its inhabitants, not called Men but Manxmen, spoke a Gaelic dialect and their legal and administrative institutions were influenced by Norse origins. Sharpe presents a preliminary analysis of the island's legal culture based on two samples of civil litigation. A peculiar feature was the absence of lawyers, although lay legal experts acted as informal lawyers.

Richard McMahon challenges the view, apparently common in Irish historiography, that in the first half of the nineteenth century practically no one wanted to give evidence as a witness in homicide trials. This supposed reluctance would have been due to active discouragement and intimidation by secret societies such as that of the Ribbon. McMahon does find some evidence of killers and their families or associates threatening witnesses in individual cases, but not of a politically motivated and concerted effort or any sustained popular hostility toward witnesses. In this area, too, most people cooperated with the law.

Greg T. Smith's contribution, entitled «Violent crime and the public weal in England, 1700-1900,» is largely a rehash of themes already well-explored by scholars such as Peter King, Robert Shoemaker and Martin Wiener. Worse, he does not even define what he means by the public weal.

Carolyn Conley stresses the Calvinist heritage in Scotland, which brought with it an emphasis on the theme of atonement in the criminal justice process. Scottish peculiarities included the distinction between a verdict of not proven and that of not guilty. Conley examines cases of infanticide, child homicide and the murder of intimates.

In spite of his name, Richard Ireland deals with Wales. He focuses on a region that, in contrast with the Isle of Man, I have read a book about, by Russell Davies, but surprisingly Ireland does not refer to it (as far as I can see without a bibliography). He concludes by admitting that he «has dragged together a number of apparently different themes, linked by the almost infinitely elastic term 'popular culture' as related to crime» (p. 252) and that is a fair characterization.

In conclusion, most but not all essays in this volume are valuable contributions to the historiography of crime, in particular violent crime, and its relationship to the law.

Pieter Spierenburg Erasmus Universiteit (Rotterdam) spierenburg@fhk.eur.nl

McLennan (Rebecca), The Crisis of Imprisonment. Protest, politics and the making of the American penal state (1776-1941), Cambridge, Cambridge University Press, 2009, 505 pp., ISBN 9780521537834.

The concept of «penal state» is familiar to me in the sense as introduced by Loïc Wacquant. He sees it as the successor to the welfare state: a régime that relies on criminalizing the surplus population of the post-industrial economy and keeping 